\title{
The research of exhaust emissions and fuel consumption from HHD engines under actual traffic conditions
}

\author{
The paper presents a comparative analysis of the emission of $\mathrm{CO}, \mathrm{NO}_{x}, \mathrm{CO}_{2}$ and gas mileage for two heavy-duty long \\ haulage vehicles. The tests were performed on the same test road. The test route reflected typical daily operation of heavy- \\ duty vehicles - a drive to the loading/unloading zone and cruise on national roads. In the investigations, the authors \\ used a portable exhaust emissions analyzer (SEMTECH DS, PEMS - Portable Emissions Measurement System). Based \\ on the performed analysis, optimum engine was selected for long haulage vehicles under conditions of Polish transport \\ and logistic infrastructure in terms of fuel consumption.
}

Key words: heavy-duty vehicle, exhaust emissions, road tests

\section{Badania emisji związków toksycznych spalin i zużycia paliwa z silników HDD w warunkach ruchu drogowego}

\begin{abstract}
W artykule przedstawiono porównanie emisji $\mathrm{CO}, \mathrm{NO}_{x}, \mathrm{CO}_{2}$ oraz przebiegowego zużycia paliwa dla dwóch pojazdów ciężkich przeznaczonych do dtugodystansowego przewozu towarów. Badania wykonano na tym samym odcinku pomiarowym. Odzwierciedlat on codzienna eksploatację pojazdów ciężkich - dojazd do miejsca załadunku/rozładunku i ruch po drogach krajowych. Do badań wykorzystano mobilny przyrzad SEMTECH DS z grupy PEMS (Portable Emissions Measurement System). Na podstawie przeprowadzonej analizy określono właściwy wybór silnika spalinowego pojazdu ciężkiego w aspekcie zużycie paliwa dla dlugodystansowego przewozu towarów w warunkach reprezentujacych krajowa infrastrukture transportowo-logistyczna.
\end{abstract}

Słowa kluczowe: pojazd ciężki, emisja gazów wylotowych, badania drogowe

\section{Introduction}

The fundamental indicator describing the dynamics of utility vehicles (heavy duty trucks and buses) is their unit power. It is the quotient of the maximum usable power of the engine and its gross vehicles weight [4-5]. In the 1950s and 1960s of the last century, heavy-duty trucks were characterized by low unit power. Due to a growth in the number of vehicles minimum values of the above-mentioned unit power were introduced for heavy-duty trucks, so that their operation did not reduce the throughput of the main roads. In the mid 1970s in Germany, a regulation was adopted that long-haulage trucks had to have a unit power of not less than $6 \mathrm{~kW} / \mathrm{t}$. This meant that a vehicle of the $\mathrm{GVW}$ of 38 tons had to have an engine of the power output of $228 \mathrm{~kW}$ (310 KM). A currently applicable unit power index is on the level of $7.5 \mathrm{~kW} / \mathrm{t}$ - introduced in 2000 . Today long-haulage vehicles are characterized by good dynamics (capability of high accelerations) [9].

European manufacturers, in their portfolios, also have vehicles fitted with engines of power output greater than 300 $\mathrm{kW}$ (this is the power output needed to obtain the unit power index of $7.5 \mathrm{~kW} / \mathrm{t}$ and Gross Vehicle Weight of $40 \mathrm{t}$ ). This is caused by a variety of economical, social, marketing-related and other aspects. Currently one of the criteria of the quality of transport services is the time of their realization. Vehicles of high unit power indexes have higher average cruising

\section{Wprowadzenie}

Podstawowym wskaźnikiem opisującym dynamikę pojazdów użytkowych (pojazdy ciężkie i autobusy) jest tzw. moc jednostkowa samochodu. Jest to iloraz maksymalnej mocy użytecznej silnika do dopuszczalnej masy całkowitej pojazdu [4-5]. W latach 50. i 60. ubiegłego wieku pojazdy ciężkie charakteryzowały się niskim wskaźnikiem mocy jednostkowej. W związku z sukcesywnym wzrostem liczby samochodów zdecydowano się wprowadzić minimalne wartości powyższego wskaźnika dla pojazdów ciężkich, aby ich eksploatacja nie powodowała spadku przepustowości głównych arterii komunikacyjnych. W połowie lat 70. XX wieku w Niemczech wprowadzono wymóg, aby pojazdy ciężkie przeznaczone do przewozów długodystansowych charakteryzowały się wskaźnikiem nie niższym niż $6 \mathrm{~kW} / \mathrm{t}$. To oznaczało, że pojazd o dmc 38 t musiał posiadać silnik spalinowy o mocy $228 \mathrm{~kW}$ (310 KM). Obowiązującym obecnie standardem jest wskaźnik na poziomie $7,5 \mathrm{~kW} / \mathrm{t}-$ wprowadzony w 2000 roku. Dzięki temu pojazdy ciężkie przeznaczone do długodystansowego przewozu towarów charakteryzują się dobrymi właściwościami dynamicznymi (zdolność do uzyskiwania dużych przyspieszeń) [8].

Europejscy producenci w swojej ofercie posiadają również pojazdy wyposażone w jednostki napędowe o mocach większych niż $300 \mathrm{~kW}$ (taką moc silnika mają pojazdy o wskaźniku 7,5 kW/t i dmc $40 \mathrm{t}$ ). Jest to 
speeds than vehicles of lower unit power indexes. This translates into shorter task realization times, hence, a greater number of transport tasks can be completed. Additionally, it is important that the vehicles of higher unit power have comparable or only slightly lower gas mileage [3]. This allows transport companies to compensate the cost of purchase of this type of vehicle. The cost of truck of higher unit power index is higher than that of trucks of a lower index.

\section{Research methodology}

\subsection{The route}

For the tests the authors selected a road portion of the length of $27 \mathrm{~km}$ (Fig. 1). The road portion well characterizes the operation of vehicles of the GVW exceeding $16000 \mathrm{~kg}$ (long haulage) in the area where the measurements were carried out. The test route started and ended in the industrial zone (point A) where a production facility is located at which approximately 50 heavy-duty vehicles are handled daily. The test road portion can be divided into two parts: a drive on the municipal roads (portion $\mathrm{A}-\mathrm{B}$ ) and national and regional roads. The drive on the national regional/roads depends on the driving direction from/to the entrance to the A2 expressway (Koło) (point D). In the case of driving to the 'Koło' expressway entrance the route went through points $\mathrm{B}-\mathrm{C}$ and $\mathrm{C}-\mathrm{D}$. In the reverse situation i.e. exiting the expressway and driving to the production facility via bypasses: points D-C and C-B (on the D-C road portion heavy duty trucks exceeding GVW of $7000 \mathrm{~kg}$ are not allowed.) The above route can be deemed representative of the national transport and logistic infrastructure - representing the road infrastructure and the distribution of production facilities in small and medium-sized towns.

\subsection{Research objects}

For the research, the authors used two heavy-duty trucks (road tractors with semi-trailers) loaded with a cargo of 20000 and $24800 \mathrm{~kg}$ (Fig. 2). The first of the objects was fitted with a $309 \mathrm{~kW}(420 \mathrm{KM})$ Euro III engine. The other object had a V8 $412 \mathrm{~kW}$ (560 KM) Euro V engine. Both vehicles were fitted with an automatic transmission (Tab. 1). Both vehicles were fitted with automatic transmission of the $12+1$ configuration. The second vehicle was also fitted with a driver monitoring system. The system, by a continuous analysis of signals from a series of sensors, provides real time hints and, upon end of trip, generates a report on the driving style. The hints and the evaluation are presented on a display and have 4 categories: driving uphill, predicting, braking and gear shifts. The idea behind the system is to continuously improve the driving skills in terms of fuel consumption and proper use of modern solutions such as: automatic transmission, retarder or EBS (Electronic Braking System). spowodowane wieloma aspektami, m.in. ekonomicznym, społecznym, marketingowym itd. Obecnie jednym z głównych kryteriów świadczącym o jakości oferowanych usług transportowych jest czas ich wykonania. Pojazdy o wyższych wskaźnikach mocy jednostkowej osiągają większe średnie prędkości przejazdu niż pojazdy o niższych wskaźnikach. Powoduje to skrócenie czasu wykonania usługi, dzięki czemu możliwa jest realizacja większej liczby zleceń transportowych. Ważne jest także, aby pojazdy te charakteryzowały się porównywalnym bądź niewiele większym przebiegowym zużyciem paliwa [3]. To pozwala firmom transportowym zrekompensować koszt zakupu tego typu pojazdów, który jest większy niż w odniesieniu do pojazdów posiadających silniki spalinowe o mniejszej mocy użytecznej.

\section{Metodyka badawcza}

\subsection{Trasa}

Do badań wykorzystano odcinek drogowy, którego długość wynosiła 27 km (rys. 1). Odcinek charakteryzuje ruch pojazdów ciężkich o dopuszczalnej masie całkowitej powyżej $16000 \mathrm{~kg}$ (tzw. długodystansowych) w miejscowości, w której przeprowadzono pomiary. Rozpoczynał się i kończył w dzielnicy przemysłowej (punkt A), gdzie znajduje się zakład produkcyjny, w którym dziennie przeładowywanych jest około 50 pojazdów ciężkich. Następnie odcinek pomiarowy można podzielić na dwie zasadnicze części: przejazd drogami miejskimi (odcinek A-B) oraz krajowymi i wojewódzkimi. Przejazd drogami

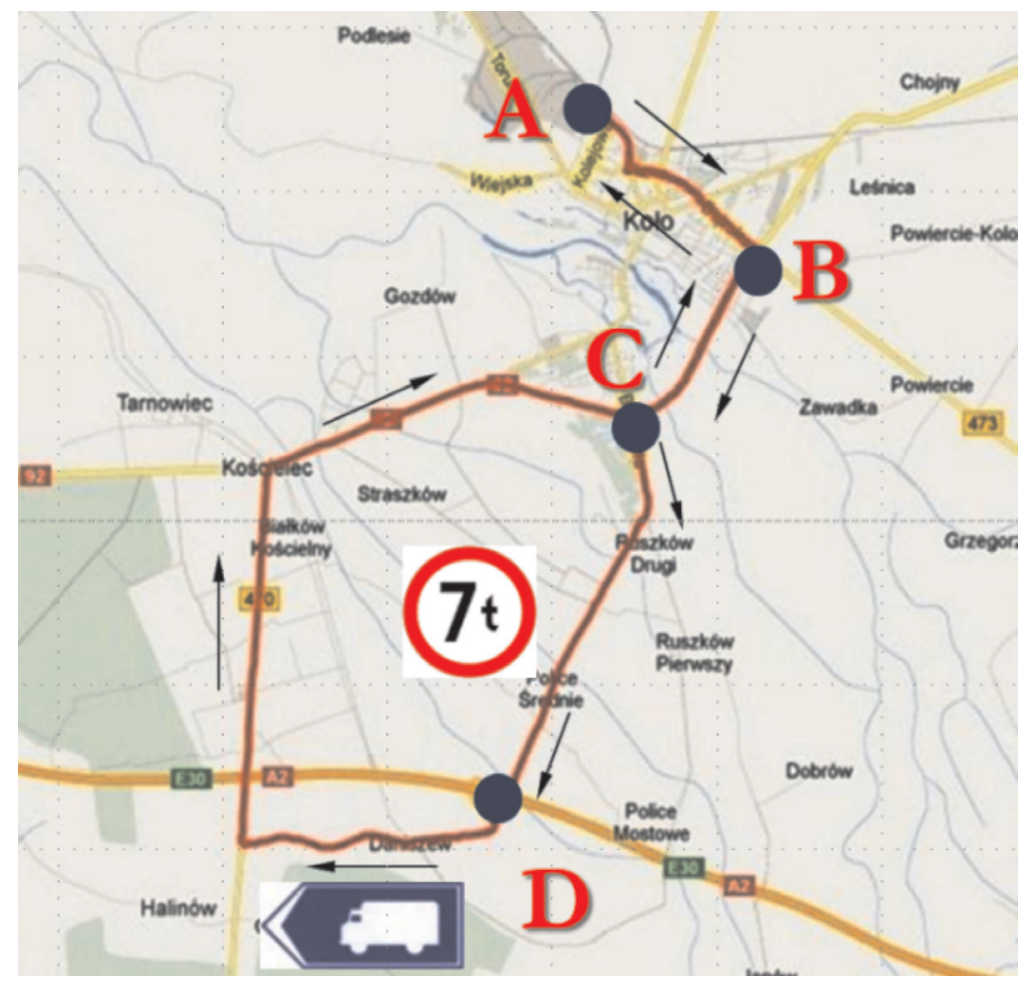

Fig. 1. The measurement road portion used in the on-road emission tests [made based on GPSVisualiser.com]

Rys. 1. Odcinek drogowy wykorzystany do badań emisji [wykonano na podstawie GPSVisualiser.com] 
a)

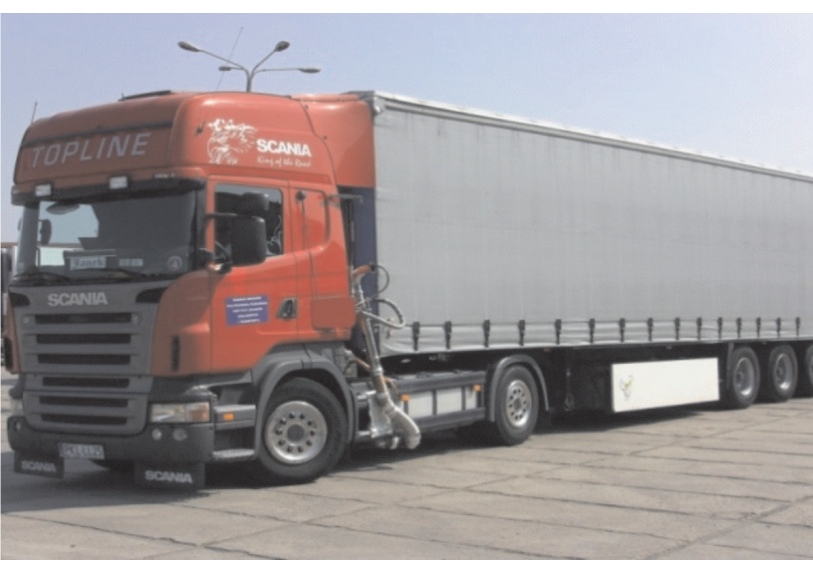

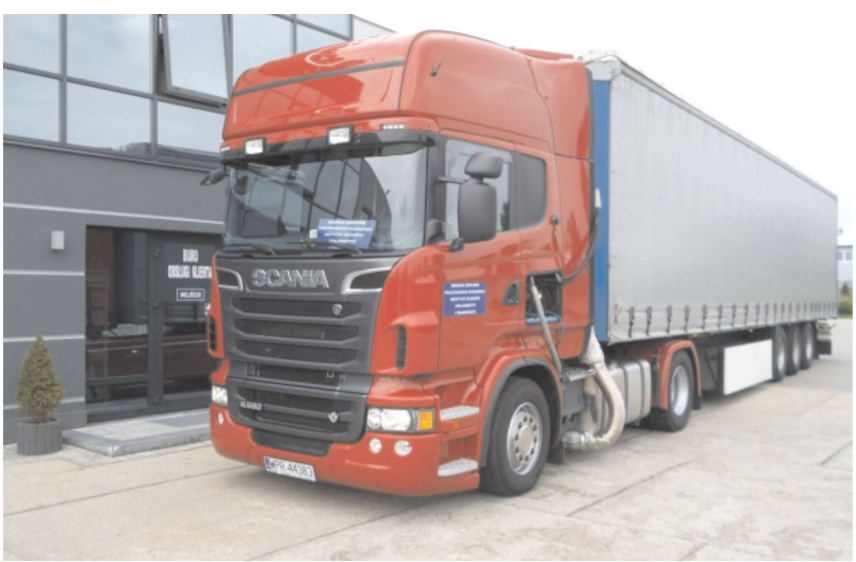

Fig. 2. Research objects during the on-road emission tests: a) vehicle A, b) vehicle B Rys. 2. Obiekty badawcze podczas drogowych badań emisyjności: a) pojazd A, b) pojazd B

\subsection{Measurement equipment}

The measurements were carried out using a portable exhaust emissions analyzer SEMTECH DS (PEMS). The device measured the emissions of $\mathrm{CO}_{2}, \mathrm{CO}$ and exhaust gas mass flow (Fig. 3a). The measurement of $\mathrm{CO}_{2}$ and $\mathrm{CO}$ was carried out with the use of NDIR (Non-Dispersive Infrared) analyzer. The devices also communicated with the vehicle diagnostic system. This connection was realized through the CAN SAE J1939 data transmission protocol. The connection allowed recording of the basic engine operating parameters such as engine speed or load. The engine load is defined in the system as the ratio of the current engine torque to its maximum torque. The vehicle position and krajowymi i wojewódzkimi zależy od kierunku jazdy do/z węzła autostrady A2 „Koło” (punkt D). W sytuacji dojazdu do węzła „Koło” trasa przebiega pomiędzy punktami B-C i C-D. W odwrotnej sytuacji, czyli dojazdu z węzła „Koło” do zakładu produkcyjnego, należy poruszać się wyznaczonym tranzytem: odcinek D-C i C-B, ponieważ na odcinku D-C obowiązuje zakaz ruchu pojazdów o dopuszczalnej masie całkowitej powyżej $7000 \mathrm{~kg}$. Powyższą trasę można uznać za reprezentatywną w aspekcie krajowego systemu transportowologistycznego - reprezentującą infrastrukturę drogową oraz usytuowanie zakładów produkcyjnych w małych i średnich miejscowościach.

Table 1. Characteristics of vehicles used for the tests [9]

Tabela 1. Charakterystyka pojazdów wykorzystanych do badań [8]

\begin{tabular}{|c|c|c|}
\hline Parameter/parametr & Vehicle/pojazd A & Vehicle/pojazd B \\
\hline Displacement/pojemność silnika & $11.7 \mathrm{dm}^{3}$ & $15.6 \mathrm{dm}^{3}$ \\
\hline Number of cylinders/arrangement/liczba cylindrów/uktad & Straight 6/6-rzędowy & $8 / \mathrm{V} 8$ \\
\hline Maximum power output/moc maks. & $\begin{array}{l}309 \mathrm{~kW} \text { at/przy } \\
1900 \mathrm{rpm} / \mathrm{obr} / \mathrm{min}\end{array}$ & $\begin{array}{c}412 \mathrm{~kW} \text { at } / \text { przy } \\
1900 \mathrm{rpm} / \mathrm{obr} / \mathrm{min}\end{array}$ \\
\hline Maximum torque/maksymalny moment obrotowy & $\begin{array}{l}2100 \mathrm{~N} \cdot \mathrm{m} \text { at } / \mathrm{przy} \\
1000-1350 \mathrm{rpm} / \mathrm{obr} / \mathrm{min}\end{array}$ & $\begin{array}{c}2700 \mathrm{~N} \cdot \mathrm{m} \text { at } / \text { przy } 1000-1400 \mathrm{rpm} / \\
\text { obr/min }\end{array}$ \\
\hline $\begin{array}{l}\text { Unit power output index/jednostkowy } \\
\text { wskaźnik mocy do masy tadunku }\end{array}$ & $7.7 \mathrm{~kW} / \mathrm{t}$ & $10.3 \mathrm{~kW} / \mathrm{t}$ \\
\hline Emission standard/norma emisji & Euro III & Euro V \\
\hline Exhaust gas aftertreatment/układ oczyszczania gazów & $\mathrm{N} / \mathrm{A} / \mathrm{brak}$ & SCR \\
\hline Transmission/skrzynia biegów & $\begin{array}{c}\text { Automatic/ } \\
\text { zautomatyzowana } 12+1\end{array}$ & $\begin{array}{c}\text { Automatic/ } \\
\text { zautomatyzowana } 12+1\end{array}$ \\
\hline $\begin{array}{l}\text { Driver support system/system monitorujacy zachowania } \\
\text { kierowcy }\end{array}$ & $\mathrm{N} / \mathrm{A} / \mathrm{brak}$ & SDS \\
\hline $\begin{array}{l}\text { Tractor axle configuration/konfiguracja osi ciagnika siodlo- } \\
\text { wego }\end{array}$ & $4 \times 2$ & $4 \times 2$ \\
\hline $\begin{array}{l}\text { Curb weight including trailer/masa własna pojazdu ciężarowe- } \\
\text { go z naczepa }\end{array}$ & $15000 \mathrm{~kg}$ & $15200 \mathrm{~kg}$ \\
\hline Cargo weight/masa ładunku & $20000 \mathrm{~kg}$ & $24800 \mathrm{~kg}$ \\
\hline Type of cargo/rodzaj tadunku & Big-Bag & Steel \\
\hline Type of trailer/typ naczepy & Canopy/kurtynowa & Canopy/kurtynowa \\
\hline
\end{tabular}




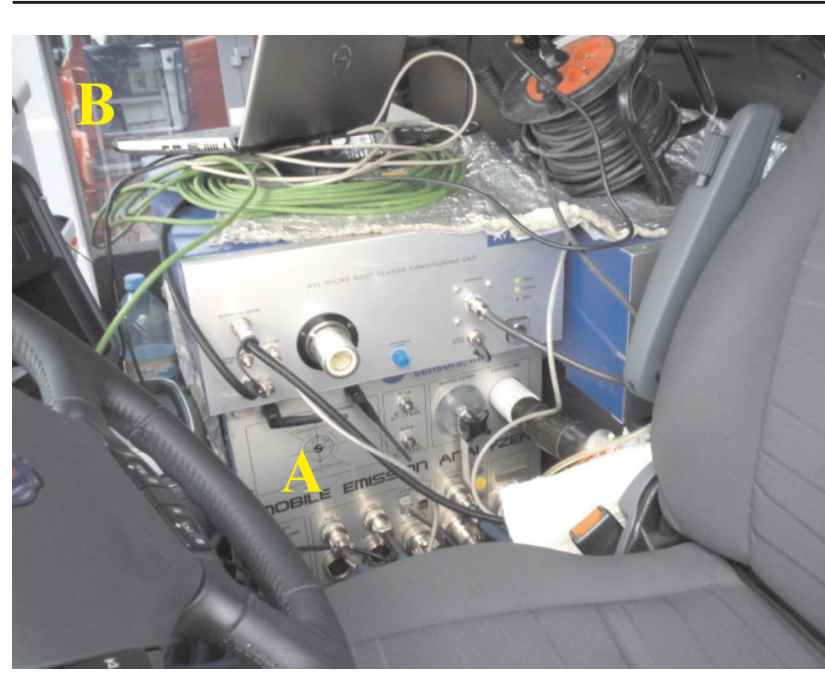

Fig. 3. Measurement equipment installed in the vehicle cab: A) SEMTECH DS, B) control laptop computer

Rys. 3. Aparatura pomiarowa zainstalowana w kabinie pojazdu ciężarowego: a) SEMTECH DS, b) komputer sterujacy praca przyrzadu

its speed were measured through the GPS system (Global Positioning System). The equipment was controlled via a laptop computer (Fig. 3b) [1, 7].

\section{The exhuast emission correction coefficient}

Because the authors could not perform the measurements on two heavy-duty vehicles of the same exhaust emissions standard, the tests were carried out for Euro III and Euro V compliant vehicles. In order to compare the obtained values of the $\mathrm{CO}$ emission the authors decided to define a dimensionless emission correction coefficient $\mathrm{C}_{\mathrm{i}}[8]$ :

$$
\mathrm{C}_{\mathrm{i}}=\frac{\mathrm{e}_{\mathrm{EuroV}}}{\mathrm{e}_{\text {EuroIII }}}
$$

where: $\mathrm{C}_{i}-$ correction coefficient of an i-th component; $e_{i}$, Euro $\mathrm{V}-\mathrm{a}$ limit of unit emission of a given component in the Euro V standard $[\mathrm{g} /(\mathrm{kW} \cdot \mathrm{h})]$; $\mathrm{e}_{\mathrm{i}}$, Euro V - a limit of unit emission of a given component in the Euro III standard $[\mathrm{g} /(\mathrm{kW} \cdot \mathrm{h})]$.

Determined values of $\mathrm{C}_{\mathrm{i}}$ coefficient shown in Table 2.

\section{Results and discussion}

\subsection{Analysis of the vehicle driving profiles}

In the first, urban part, significant differences in the driving profiles of both vehicles were recorded. Vehicle A had a higher speed than vehicle B (Fig. 4, Tab. 3). This was caused by higher traffic congestion during the test run of vehicle $B$. In the rural part, both driving profiles were similar. Vehicle A, during the entire run had a lower average speed (by $5 \%$ ) than vehicle B. From the analysis of the maximum and average acceleration in the acceleration phase it results that vehicle B was more dynamic because in both cases its values were higher by 49 and $19 \%$ respectively.

\subsection{Analysis of the exhaust emissions}

According to the previous assumption (chapter 3) the second-by-second emission of $\mathrm{CO}$ and $\mathrm{NO}_{\mathrm{x}}$ of vehicle $\mathrm{A}$

\subsection{Obiekty badawcze}

Do badań wykorzystano dwa pojazdy ciężkie (ciągniki siodłowe $\mathrm{z}$ naczepami) obciążone odpowiednio ładunkiem 20000 i 24800 kg (rys. 2). Pierwszy z obiektów wyposażony był w silnik spalinowy o mocy 309 kW (420 KM) spełniający normę emisji Euro III. Drugi obiekt posiadał silnik V8 o mocy 412 kW (560 KM), który spełniał normę emisji Euro V (tab. 1). Oba pojazdy posiadały zautomatyzowane skrzynie biegów o konfiguracji $12+1$. Drugi pojazd posiadał również system monitorujący działania kierowcy, który przez ciągłą analizę danych pochodzących z różnych czujników na bieżąco wyświetla wskazówki do zachowania ekonomicznego stylu jazdy, a po zakończeniu przejazdu generuje podsumowanie z oceną stylu. Wskazówki i oceny są prezentowane na wyświetlaczu i obejmują cztery kategorie: jazda na wzniesieniach, przewidywanie, hamowanie oraz zmiana biegów. Zadaniem systemu jest ciągłe doskonalenie umiejętności kierowcy w aspekcie ograniczenia zużycia paliwa przez odpowiednie wykorzystywanie stosowanych nowoczesnych rozwiązań w pojazdach ciężarowych, takich jak: zautomatyzowana skrzynia biegów, retarder czy układ EBS (Electronic Breaking System).

\subsection{Aparatura pomiarowa}

Pomiary przeprowadzono przy użyciu mobilnego analizatora gazów wylotowych SEMTECH DS z grupy PEMS, który umożliwiał pomiar $\mathrm{CO}_{2}, \mathrm{CO}, \mathrm{NO}_{\mathrm{x}}\left(\mathrm{NO}+\mathrm{NO}_{2}\right)$ oraz masowego natężenia przepływu gazów wylotowych (rys. 3a). Pomiaru $\mathrm{CO}_{2}$ i CO dokonano przy użyciu analizatora NDIR (Non-Dispersive Infrared), a pomiaru $\mathrm{NO}_{\mathrm{x}}$ przy użyciu analizatora NDUV (Non-Dispersive Ultraviolet). Przyrząd posiada także funkcję komunikacji z siecią diagnostyczną pojazdu. To połączenie zrealizowano za pomocą protokołu transmisji danych CAN SAE J1939. Dzięki temu dokonano rejestracji podstawowych parametrów pracy silnika spalinowego, takich jak prędkość obrotowa wału korbowego, czy generowane obciążenie, które wyrażone jest stosunkiem bieżącego momentu obrotowego i maksymalnego momentu obrotowego przy danej prędkości obrotowej wału korbowego

Table 2. Values of the emissions limit and Ci coefficient

Tabela 2. Wartości emisji jednostkowej i wskaźnika korygującego Ci

\begin{tabular}{|c|c|c|c|}
\hline & $\begin{array}{c}\text { Euro III } \\
{[\mathrm{g} /(\mathrm{kW} \cdot \mathrm{h})]}\end{array}$ & $\begin{array}{c}\text { Euro V } \\
{[\mathrm{g} /(\mathrm{kW} \cdot \mathrm{h})]}\end{array}$ & $\begin{array}{c}\text { Wskaźnik } \mathrm{C}_{\mathrm{i}} \\
{[-]}\end{array}$ \\
\hline $\mathrm{CO}$ & 2.10 & 1.50 & 0.72 \\
\hline NOx & 5.00 & 2.00 & 0.40 \\
\hline
\end{tabular}

silnika. Pozycję pojazdu oraz jego prędkość zmierzono za pomocą układu pozycjonowania GPS (Global Positioning System). Sterowanie pracą przyrządu obywało się przy wykorzystaniu komputera osobistego połączonego z aparaturą za pomocą sieci Wi-Fi (rys. 3b) [1, 6].

\section{Wskaźnik korygujący emisję toksycznych skladników gazów wylotowych}

Ze względu na brak możliwości przebadania dwóch pojazdów ciężkich spełniających tę samą normę emisji, 
was multiplied by index $\mathrm{C}_{\mathrm{i}}$ and then compared with the course recorded for vehicle B. Vehicle A in the first, urban phase had higher maximum values of the emission of $\mathrm{CO}$ than vehicle $\mathrm{B}$ (Fig. 5). In the further part of the test run this trend was preserved except several points (emission peaks). Despite the correction of the second-by-second emission of $\mathrm{CO}$ by the value of $\mathrm{C}_{\mathrm{i}}$, vehicle A had higher average emission of $\mathrm{CO}$ than vehicle $\mathrm{B}$ - the average emission of $\mathrm{CO}$ was 27.07 and $22.83 \mathrm{mg} / \mathrm{s}$ respectively. Analyzing the second-by-second emission of $\mathrm{NO}_{x}$ the authors observed that in the first, urban phase vehicle $B$ had higher values

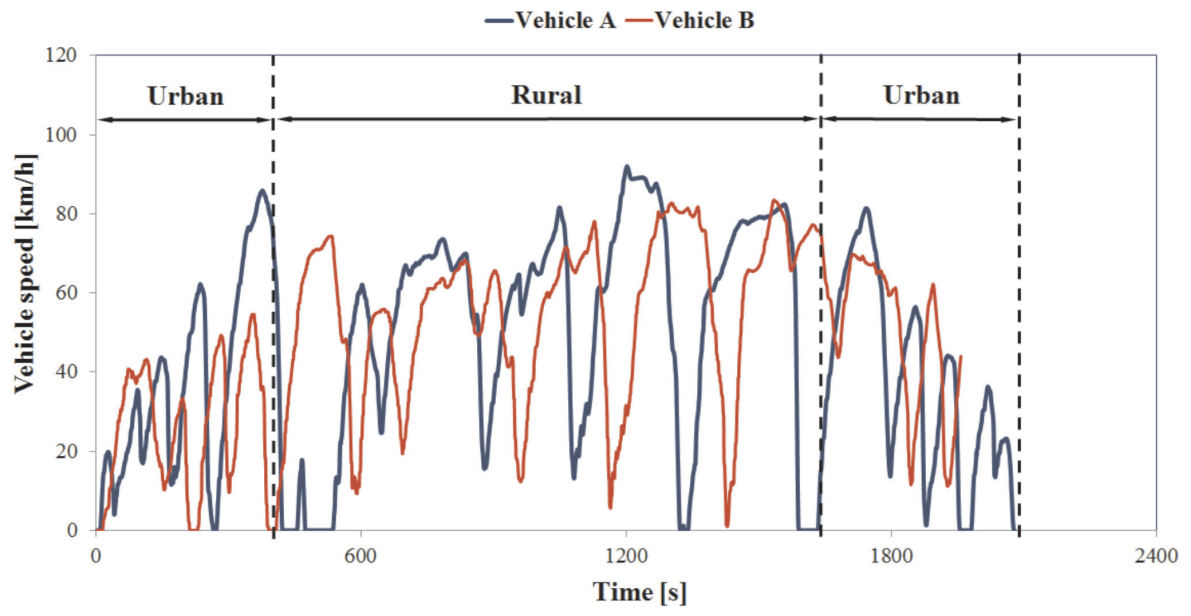

Fig. 4. Speed profiles of the tested vehicles obtained during the on-road tests described with function $\mathrm{f}=\mathrm{V}(\mathrm{t})$

Rys. 4. Profile prędkości badanych pojazdów uzyskane podczas badań drogowych opisane funkcją $f=V(t)$

of this emission than vehicle A(Fig. 6). In the further part of the test, this trend changed and vehicle A had higher emissions. Such a situation was caused by the SCR (selective catalytic reduction) system responsible for the control of the $\mathrm{NO}_{\mathrm{x}}$ emission fitted in the exhaust of vehicle $\mathrm{B}$. In the first phase of the test, the SCR system was probably inhibited, as the tests for both vehicles were initiated from a cold start (a cold start is to be construed in this case as starting the engine at an ambient temperature of over $20^{\circ} \mathrm{C}$ ) and under these conditions the exhaust gas temperature is too low for the $\mathrm{NO}_{\mathrm{x}}$ reduction to occur when a $32.5 \%$ water solution of urea is applied. Upon stabilization of the engine thermal state, a growth of the exhaust gas temperature takes place thus generating proper conditions for the reduction of $\mathrm{NO}_{\mathrm{x}}$. The temperature of the exhaust gas also influences the conversion rate of the SCR catalytic converter where the said reactions take place. In standard SCR converters, the highest conversion rate occurs for $250-400^{\circ} \mathrm{C}$. Under such conditions the SCR control system initiates injection of a $32.5 \%$ solution of urea into the vehicle exhaust system, from which, following a series of reactions, ammonia is badania przeprowadzono dla pojazdu spełniającego normę Euro III i V. Aby porównać uzyskane wartości, podczas pomiarów drogowych zdefiniowano bezwymiarowy wskaźnik korygujący emisję $C_{i}[7]$ - wzór (1),

gdzie: $\mathrm{C}_{\mathrm{i}}$ - wskaźnik korygujący emisję i-tego związku, $\mathrm{e}_{\text {EuroV }}$ - limit emisji jednostkowej danego związku w normie Euro V [g/(kW·h)], $e_{\text {Euro III }}$ - limit emisji jednostkowej danego związku w normie Euro III $[\mathrm{g} /(\mathrm{kW} \cdot \mathrm{h})]$.

Wyznaczone wartości wskaźnika Ci przedstawiono w tabeli 2.

\section{Wyniki pomiarów - dyskusja}

\subsection{Analiza profili ruchu pojazdów}

W pierwszej części miejskiej testu badawczego zarejestrowano znaczące różnice pomiędzy profilami ruchu obu pojazdów: pojazd A osiągnął większą prędkość niż pojazd B (rys. 4, tab.3). To było spowodowane przede wszystkim większym natężeniem ruchu pojazdów podczas przejazdu pojazdu B. W części pozamiejskiej oba profile ruchu charakteryzowały się zbliżonym przebiegiem. Pojazd A podczas całego przejazdu uzyskał mniejszą średnią prędkość o $5 \%$

Table 3. Parameters characterizing the test runs of both vehicles during the on-road tests

Tabela 3. Parametry charakteryzujące przejazdy obu pojazdów podczas badań drogowych

\begin{tabular}{|l|c|c|c|c|}
\hline Parameter/parametr & $\begin{array}{c}\text { Unit/ } \\
\text { jednostka }\end{array}$ & $\begin{array}{c}\text { Vehicle/ } \\
\text { pojazd } \mathrm{A}\end{array}$ & $\begin{array}{c}\text { Vehicle/ } \\
\text { pojazd } \mathrm{B}\end{array}$ & $\begin{array}{c}\text { Percentage ratio vehicle A/vehicle B/stosunek } \\
\text { procentowy pojazdu A do pojazdu B }[\%]\end{array}$ \\
\hline Distance s/droga & $\mathrm{km}$ & 26.57 & 26.88 & 98.84 \\
\hline Maximum speed/prędkość maks. $\mathrm{V}_{\max }$ & $\mathrm{km} / \mathrm{h}$ & 92.00 & 84.52 & 108.14 \\
\hline $\begin{array}{l}\text { Average speed/ } \\
\text { prędkość średnia } \mathrm{V}_{\text {sr }}\end{array}$ & $\mathrm{km} / \mathrm{h}$ & 45.73 & 48.56 & 94.17 \\
\hline $\begin{array}{l}\text { Minimum acceleration/ } \\
\text { przyspieszenie } \\
\text { minimalne } \mathrm{a}_{\min }\end{array}$ & $\mathrm{m} / \mathrm{s}^{2}$ & -2.93 & -2.80 & 104.64 \\
\hline $\begin{array}{l}\text { Maximum acceleration/przyspieszenie } \\
\text { maksymalne } \mathrm{a}_{\max }\end{array}$ & $\mathrm{m} / \mathrm{s}^{2}$ & 1.28 & 2.53 & \\
\hline $\begin{array}{l}\text { Average acceleration in phase of the } \\
\text { ramp-up/przyspieszenie średnie } w \text { fazie } \\
\text { rozpędzania } \mathrm{a}_{\text {sr }}\end{array}$ & $\mathrm{m} / \mathrm{s}^{2}$ & 0.21 & 0.26 & \\
\hline
\end{tabular}




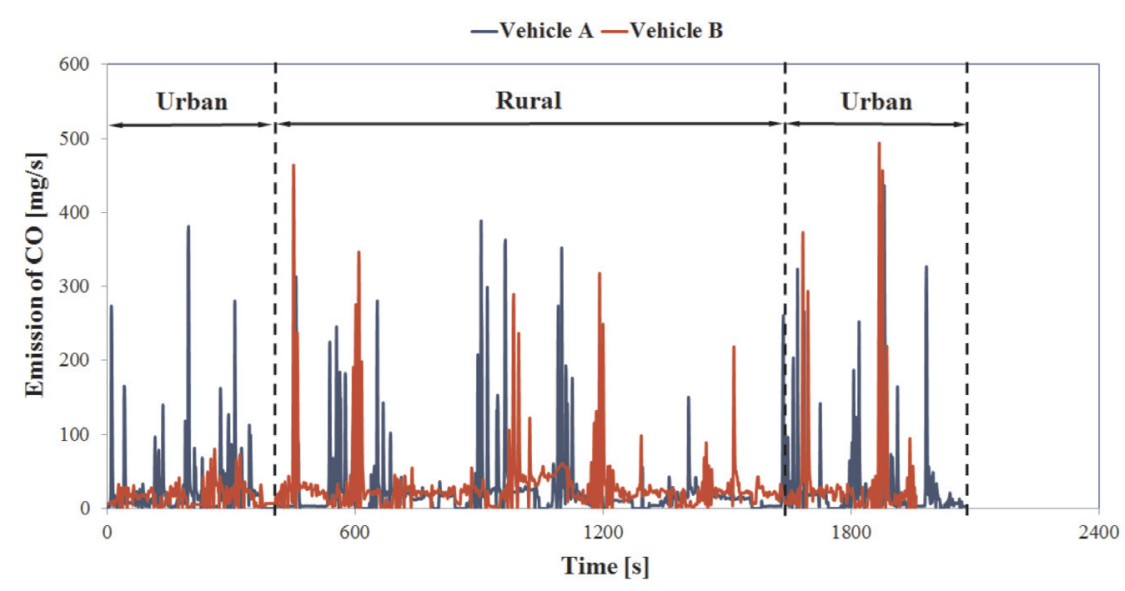

Fig. 5. The tracing of the second-by-second emission of $\mathrm{CO}$ for both vehicles obtained during the on-road tests

Rys. 5. Przebiegi natężenia emisji CO dla obu pojazdów uzyskane podczas badań drogowych niż pojazd B. Z analizy maksymalnego i średniego przyspieszenia w fazie rozpędzania wynika, że przejazd pojazdu B był bardziej dynamiczny, ponieważ w obu przypadku uzyskano większe jego wartości, odpowiednio o $49 \%$ i $19 \%$.

\subsection{Analiza emisji toksycznych składników gazów wylotowych}

Według przyjętego wcześniej założenia (rozdz. 3) wartość natężenia emisji $\mathrm{CO}$ i NO pojazdu A przemnożono przez wskaźnik $\mathrm{C}_{\mathrm{i}} \mathrm{i}$ następnie porównano z przebiegiem zarejestrowanym dla pojazdu B. Pojazd A w pierwszej fazie miejskiej uzyskał większe maksymalne wartości emisji CO niż pojazd B (rys. 5). W dalszej części odcinka pomiarowego tendencja ta została

generated and used in the selective reduction of $\mathrm{NO}_{x}$. From the recorded course of the secondby-second emission of $\mathrm{NO}_{x}$ it results that the SCR system had obtained the highest conversion rate after 600 seconds of the test run and then vehicle $B$ obtained much lower values of emission than in the initial phase of the test. In this part of the test vehicle $\mathrm{B}$ also had lower emission of $\mathrm{NO}_{x}$ than vehicle $\mathrm{A}$.

As for the second-by-second emission of $\mathrm{CO}_{2}$, for both vehicles a similar course was recorded (Fig. 7). The highest maximum values of $\mathrm{CO}_{2}$ for both vehicles were in the rural cycle. This can be attributed to

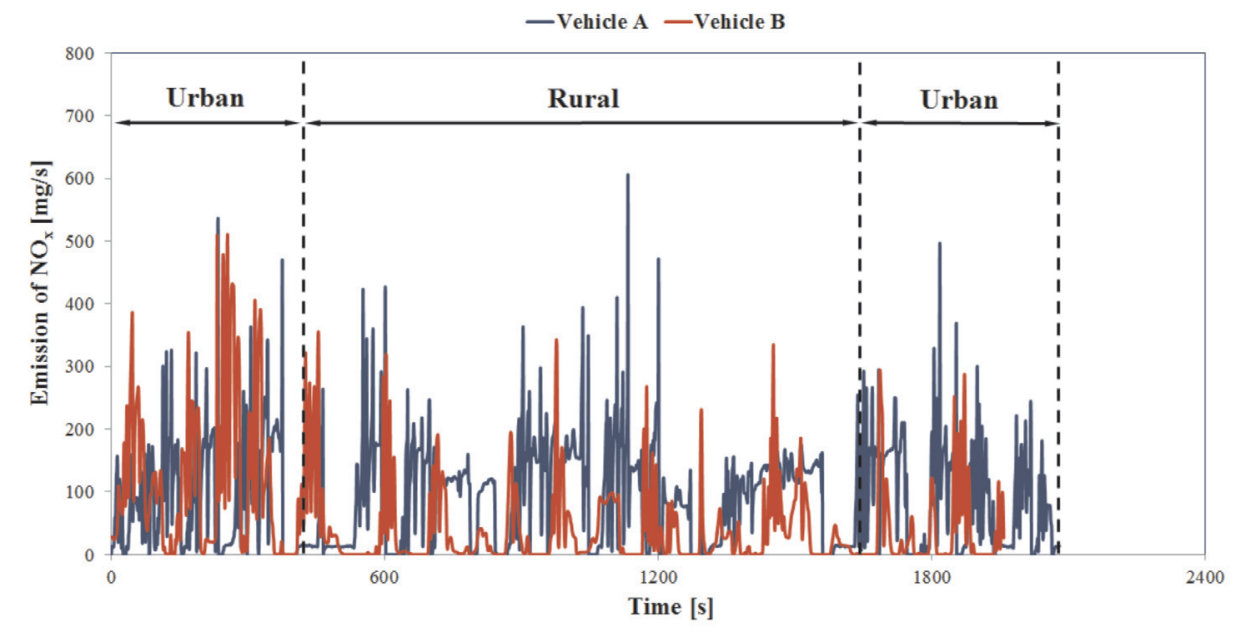

Fig. 6. The tracing of the second-by-second emission of $\mathrm{NO}_{x}$ for both vehicles obtained during the on-road tests

Rys. 6. Przebiegi natężenia emisji NO dla obu pojazdów uzyskane podczas badań drogowych

—Vehicle A — Vehicle B

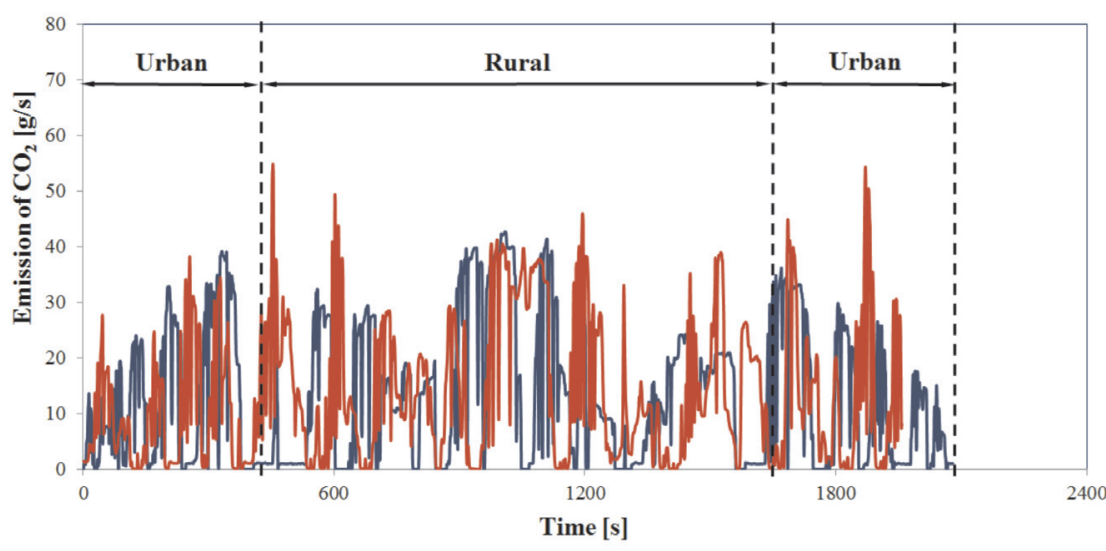

Fig. 7. The tracing of the second-by-second emission of $\mathrm{CO}_{2}$ for both vehicles obtained during the on-road tests

Rys. 7. Przebiegi natężenia emisji $\mathrm{CO}_{2}$ dla obu pojazdów uzyskane podczas badań drogowych zachowana, z wyjątkiem kilku pojedynczych punktów, tzw. pików emisji. Mimo korekty natężenia emisji CO o wartość wskaźnika $C_{i}$ pojazd A uzyskał większe średnie natężenie emisji CO niż pojazd B - średnie natężenie emisji CO wyniosło odpowiednio 27,07 i $22,83 \mathrm{mg} / \mathrm{s}$. Analizując natężenie emisji $\mathrm{NO}_{\mathrm{x}}$ stwierdzono, że w pierwszej fazie miejskiej pojazd B uzyskał większe jej wartości niż pojazd A (rys. 6). W dalszej części testu tendencja ta uległa zmianie i pojazd A uzyskiwał większe wartości emisji. Taki przebieg spowodowany był działaniem zamontowanego w układzie wylotowym pojazdu B układu SCR (Selective Catalytic Reduction) odpowiedzial- 


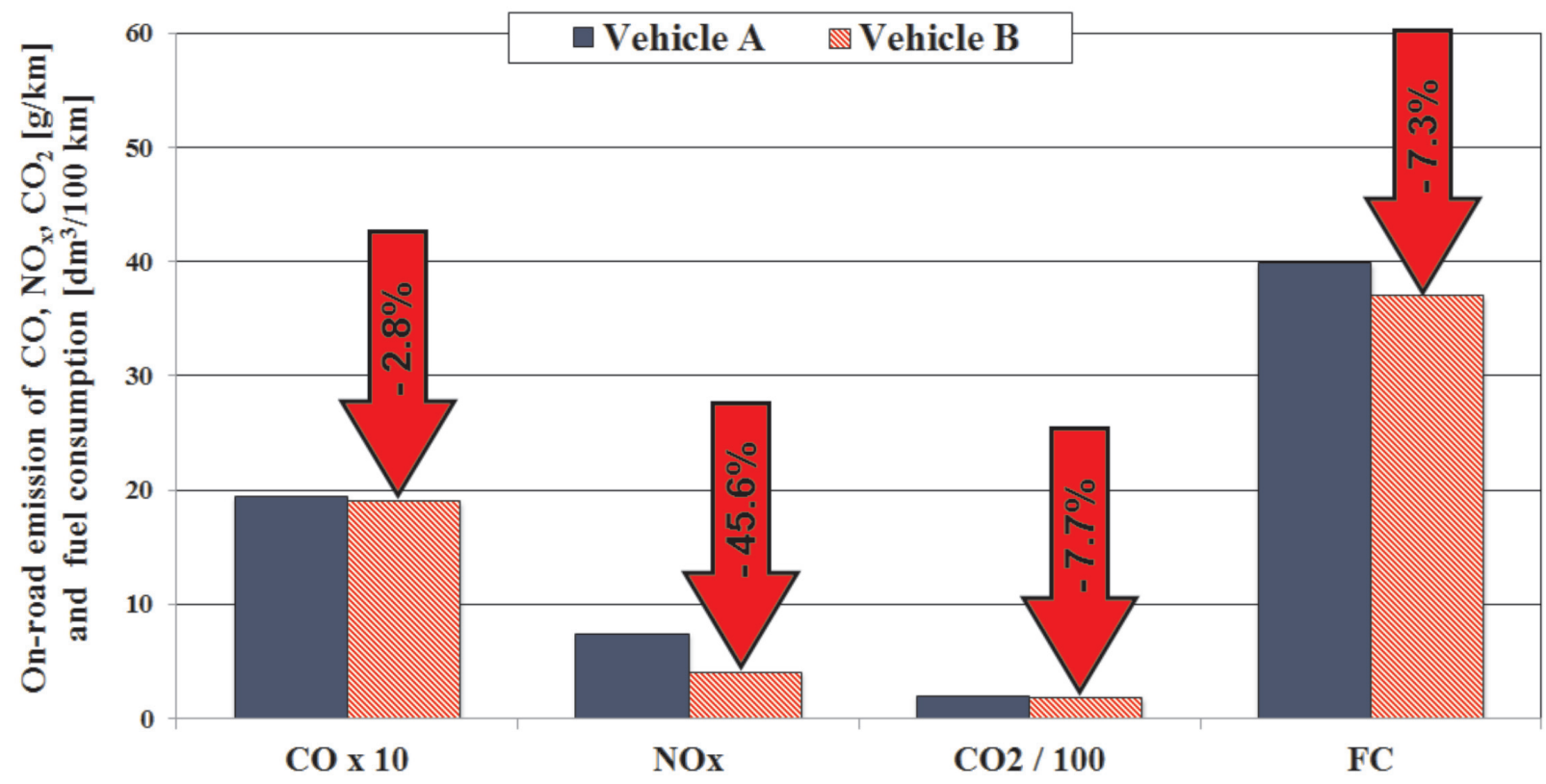

Fig. 8. Comparison of the on-road emission of $\mathrm{CO}_{2}, \mathrm{CO}$ and gas mileage of the tested vehicles Rys. 8. Porównanie emisji drogowej $\mathrm{CO}, \mathrm{NO}_{x}, \mathrm{CO}_{2}$ oraz przebiegowego zużycia paliwa badanych pojazdów

high cruising speeds, thus, greater energy demand of the research objects. In the last part of the test, a series of work points was recorded at which a significant increase in the second-by-second emission of $\mathrm{CO}_{2}$ occurred for vehicle $\mathrm{B}$. This was attributed to greater average acceleration compared to vehicle A.

As for the second-by-second emission of $\mathrm{CO}_{2}$ for both vehicles, similar course of this emission was recorded (Fig. 7). The highest maximum values of the emission of $\mathrm{CO}_{2}$ for both vehicles were in the expressway phase. This was related to the speeds, hence, the energy demands of the tested vehicles. In the last phase, a series of points was recorded where significant growth in the second-by-second emission of $\mathrm{CO}_{2}$ for vehicle B was observed. This was caused by a greater average acceleration of vehicle B compared to vehicle A.

Next, based on the carbon balance method [2], the gas mileage for both vehicles was determined (in this method, the on-road emission of $\mathrm{CO}_{2}, \mathrm{CO}$ and $\mathrm{HC}$ is taken into account). Figure 8 presents the comparison of the on-road emissions of $\mathrm{CO}_{2}, \mathrm{CO}$ and the gas mileage. In all cases, vehicle $\mathrm{B}$ obtained lower values and a higher gas mileage. It is noteworthy that it had a significant increase in the gas mileage (by $2.9 \mathrm{dm}^{3} / 100 \mathrm{~km}$ ). The cost of fuel is currently the main cost of operation of long-haulage trucks. The greatest drop was observed for the on-road emission of $\mathrm{NO}_{x}$, that mainly resulted from the application of the SCR system in vehicle B.

\section{Conclusions}

From the performed analysis we know that the heavyduty vehicle characterized by the greatest unit power (B) had better emission performance $\left(\mathrm{CO}_{2}, \mathrm{CO}, \mathrm{NO}_{\mathrm{x}}\right)$ and better gas mileage. Greater values of the average acceleration in nego za redukcję $\mathrm{NO}_{x}$. W pierwszej fazie testu układ SCR najprawdopodobniej był nieaktywny, ponieważ testy dla obu pojazdów rozpoczynano od zimnego rozruchu (zimny rozruch w tym przypadku należy rozumieć jako uruchomienie silnika przy temperaturze powietrza atmosferycznego wynoszącej ponad $20^{\circ} \mathrm{C}$ ) i w tych warunkach temperatura gazów wylotowych jest zbyt niska, aby zachodziły reakcje redukcji $\mathrm{NO}_{\mathrm{x}}$ przy wykorzystaniu $32,5 \%$ wodnego roztworu mocznika. Po ustabilizowaniu stanu cieplnego silnika następuje wzrost temperatury gazów wylotowych, stwarzając tym samym atmosferę sprzyjającą zajściu reakcji redukcji $\mathrm{NO}_{\mathrm{x}}$. Temperatura gazów wylotowych wpływa również na stopień konwersji reaktora katalitycznego SCR, w którym zachodzą wspomniane reakcje. W standardowych układach SCR największy stopień konwersji reaktora katalitycznego występuje dla $250-400{ }^{\circ} \mathrm{C}$. W takich warunkach system sterujący pracą układu SCR rozpoczyna wtrysk roztworu mocznika do układu wylotowego silnika, z którego w wyniku reakcji chemicznych powstaje amoniak wykorzystywany w reakcjach selektywnej redukcji $\mathrm{NO}_{\mathrm{x}}$. Z zarejestrowanego przebiegu natężenia emisji $\mathrm{NO}_{x}$ wynika, że układ SCR osiągnął największy stopień konwersji po 600 sekundach testu i wtedy pojazd B uzyskiwał znacznie mniejsze jej wartości niż w początkowej fazie testu. W tej części testu pojazd B uzyskał również mniejszą emisję $\mathrm{NO}_{\mathrm{x}}$ niż pojazd $\mathrm{A}$.

W sytuacji natężenia emisji $\mathrm{CO}_{2}$ dla obu pojazdów zarejestrowano podobny jej przebieg (rys. 7). Największe maksymalne wartości emisji $\mathrm{CO}_{2}$ dla obu pojazdów wystąpiły w fazie pozamiejskiej. Związane to było z dużymi prędkościami, a tym samym z większym zapotrzebowaniem energetycznym silników spalinowych obiektów badawczych. W ostatniej fazie testu zarejestrowano punkty pracy, 
the acceleration phase and the average speed obtained on the test run by vehicle B confirm its better dynamics. This fact clearly has impact on the traveling time, thus reducing the time of realization of a transport task. The increase in the gas mileage in the long run will bring measurable economic results and will contribute to better environmental performance of the road transport sector. The above factors will significantly influence the efficiency of the transport services. The above facts confirm the applicability of vehicle of higher unit power index.

\section{Bibliography/Literatura}

[1] Merkisz J., Fuć P.: The Exhaust Emission from Light Duty Vehicles in Road Test in Urban Traffic. SAE Technical Paper Series 2010-01-1558, 2010.

[2] Merkisz J., Fuć P., Ziółkowski A.: Wpływ masy ładunku na emisję $\mathrm{CO}_{2}, \mathrm{NO}_{x}$ i na zużycie paliwa pojazdu ciężarowego o masie całkowitej powyżej $12000 \mathrm{~kg}$. Postępy Nauki i Techniki/Advances in Science and Technology nr 15/2012; 2012.

[3] Merkisz J., Kozak M., Nijak D., Andrzejewski M., Molik P., Nowak M., Rymaniak L., Ziolkowski A.: The analysis of the emission level from heavy-duty truck in a city traffic. Combustion Engines nr 3/2012 (151), pp. 80-88.

[4] Prochowski L.: Pojazdy samochodowe. Mechanika ruchu. Wydawnictwa Komunikacji i Łączności, Warszawa 2005.

[5] Prochowski L., Żuchowski A.: Pojazdy samochodowe. Samochody ciężarowe i autobusy. Wydawnictwa Komunikacji i Łączności, Warszawa 2011.

[6] www.sensors-inc.com

[7] Information from Worldwide Emissions Standards. Passenger Cars \& Light Duty Vehicles. Delphi brochure 2010/2011. delphi.com/pdf/emissions/Delphi-Passenger-Car-Light-DutyTruck-Emissions-Brochure-2011-2012.pdf.

[8] Materiały informacyjne otrzymane od producentów pojazdów ciężarowych. w których nastąpił znaczny wzrost natężenia emisji $\mathrm{CO}_{2}$ dla pojazdu B. To było uwarunkowane większym średnim przyspieszeniem niż dla pojazdu A.

Następnie na podstawie metody bilansu węgla [2] wyznaczono wartości przebiegowego zużycia paliwa dla obu pojazdów. W tej metodzie uwzględniania jest emisja drogowa $\mathrm{CO}_{2}, \mathrm{CO}$ i HC. Na rysunku 8 przedstawiono porównanie emisji drogowej $\mathrm{CO}_{2}, \mathrm{CO}$ oraz przebiegowego zużycia paliwa. We wszystkich przypadkach pojazd B uzyskał mniejsze wartości. Na szczególną uwagę zasługuje znaczący spadek przebiegowego zużycia paliwa (o $2,9 \mathrm{dm}^{3} / 100 \mathrm{~km}$ ), ponieważ jest ono obecnie głównym kosztem eksploatacji pojazdów ciężarowych przeznaczonych do długodystansowego transportu towarów. Największy spadek emisji drogowej zarejestrowano dla $\mathrm{NO}$, który wynikał głównie z zastosowania układu SCR w układzie wylotowym pojazdu B.

\section{Wnioski}

Z przeprowadzonej analizy wynika, że pojazd ciężki charakteryzujący się wyższym wskaźnikiem mocy jednostkowej (B) uzyskał zarówno mniejszą emisję drogową $\mathrm{CO}_{2}, \mathrm{CO}$, $\mathrm{NO}_{\mathrm{x}}$, jak i przebiegowe zużycie paliwa. Większe wartości średniego przyspieszenia $\mathrm{w}$ fazie rozpędzania $\mathrm{i}$ średniej prędkości otrzymane na trasie pomiarowej przez pojazd B świadczą o jego korzystniejszych właściwościach dynamicznych. Obniżenie przebiegowego zużycia paliwa w dłuższej perspektywie przyniesie wymierne korzyści ekonomiczne oraz przyczyni się do ograniczenia negatywnego wpływu na środowisko naturalne sektora transportu drogowego. Powyższe czynniki znacząco wpłyną na poprawę efektywności usług oferowanych przez przedsiębiorstwa transportowe. Podane fakty potwierdzają słuszność stosowania pojazdów o wyższym jednostkowym wskaźniku mocy.

Prof. Jerzy Merkisz, DSc., DEng. - Professor in the Faculty of Machines and Transport at Poznan University of Technology.

Prof. Jerzy Merkisz - profesor na Wydziale Maszyn Roboczych i Transportu Politechniki Poznańskiej.

e-mail:jerzy.merkisz@put.poznan.pl

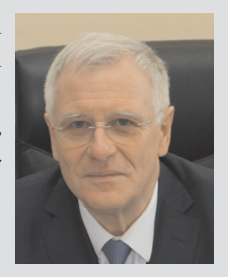

Paweł Fuć, DSc., DEng. - doctor, Institute of Combustion Engines and Transport at Poznan University of Technology.

Dr hab. inż. Pawel Fuć - adiunkt w Instytucie Silników Spalinowych i Transportu Politechniki Poznańskiej.

e-mail:pawel.fuc@put.poznan.pl

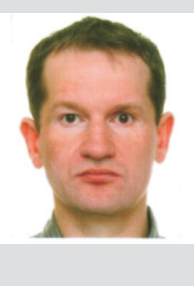

Łukasz Rymaniak, MSc., Eng. - PhD student in the Faculty of Machines and Transport at Poznan University of Technology.

Mgrinż. Lukasz Rymaniak-doktorant na Wydziale Maszyn Roboczych i Transportu Politechniki Poznańskiej.

e-mail: rymaniak.lukasz@onet.eu

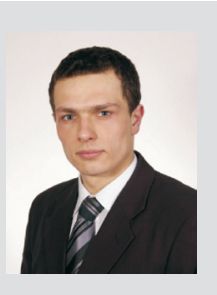

